\title{
Das Alte Cestament und die Ausgrabungen
}

Ein Beitrag zum Streit um Babel und Bibel

von

\author{
D. Karl Budde
}

ord. prof. d. Cheologie a. d. Anfv. Marburg

Zweite Huflage

mft vielen Anmerkungen

undeinem vorwortestatt des Nachworts.

\section{Giessen}

3. Ricker'sche Verlagobuchbandlung

(Alfred Cöpelmann)

1903. 
Druck von C. G. Röder, Leipzig. 